\title{
WAWASAN MULTIKULTURAL DALAM SUPERVISI AKADEMIK PENDIDIKAN AGAMA ISLAM ASPEK FIQIH DI SMP NEGERI KABUPATEN SINTANG
}

\author{
ILHAMDI \\ Chief of Teacher Associaion PAI Kabupaten Sintang Provinsi Kalimantan Barat \\ E-mail: ilhamdi.sintang@gmail.com
}

\begin{abstract}
Abstrac
This study is an attempt to correct Islamic education (PAI), improving the competence of teachers and supervisors. This study used qualitative methods. To analyze the data used descriptive analysis. Based on the result of the research that the material content of Islamic education Junior hight School aspects of Fiqh for classes VII, VIII, and IX class semester of odd and even do not incorporate the principles of sound multicultural. As well as in academic supervisory planning document (RKA) PAI supervisor Academic Year 2013/2014 of odd and even semester still focused on the learning process and the administration of teacher.
\end{abstract}

Keywords: Academic plan supervisory (RKA), Aspects of Fiqh at PAI, and Multicultural

\begin{abstract}
Abstrak
Penelitian ini adalah upaya untuk memperbaiki pendidikan agama Islam (PAI), meningkatkan kompetensi guru dan pengawas. Penelitian ini menggunakan metode kualitatif. Untuk menganalisis data penelitian digunakan analisis deskriptif. Hasil penelitian bahwa isi materi pendidikan agama Islam SMP aspek fiqih untuk kelas VII, VIII, dan kelas IX semester ganjil dan genap tidak memuat prinsip-prinsip yang berwawasan multikultural. Begitu juga dalam dokumen rencana kepengawasan akademik (RKA) pengawas PAI Tahun Pelajaran 2013/2014 semester ganjil dan genap masih difokuskan pada proses pembelajaran dan administrasi guru.
\end{abstract}

Kata Kunci: Rencana Kepengawasan Akademik (RKA), PAI Aspek Fiqih, dan Multikultural.

\section{PENDAHULUAN}

\section{Latar Belakang Masalah}

Keragaman khususnya dalam agama, dapat menimbulkan berbagai konflik. ${ }^{1}$ Konflik terbuka antar (umat) beragama baik eksternal maupun internal itu muncul lantaran adanya paham keagamaan yang ekslusif walaupun bukan satu-satunya penyebab. Namun, agama telah memberikan kontribusi besar terhadap munculnya konflik di beberapa daerah. ${ }^{2}$

\footnotetext{
${ }^{1}$ M. Amin Abdullah, Studi Agama, (Yogyakarta: Pustaka Pelajar, 1996), hlm. 5; Ahmad Syahid, "Peta Kerukunan Umat Beragama Provinsi Bengkulu, (seri II), dalam Riuh Di Beranda Satu, (Jakarta: Depag RI, 2003), hlm. 1-2

${ }^{2}$ Syamsul Arifin, Silang Sengkarut Agama di Ranah Sosial Tentang Konflik, Kekerasan Agama dan Nalar Multikulturalisme, (Malang: UMM Press, 2009), hlm. 13
} 
Dalam realitas perjalanan sejarah keagamaan, khususnya Islam, pasca meninggalnya Rasulullah saw, mulai terjadi banyak pergeseran nilai. Sejarah mencatat konflik dan perang antara Bani Umayyah dan Bani Abbasiyah adalah contoh paling nyata bagaimana semangat ajaran Islam berjalan seiring dengan ambisi dinatisme dan fanatisme mazhab yang tidak segan-segan menggunakan kekerasan untuk menindas sesama muslim. Begitu pun, dalam konteks kekinian, sering kita kita menemukan fenomena empirikketika terjadi perbedaan paham keagamaan tidak jarang dihadapi dengan kekerasan, bukan dengan dialog yang cerdas dan saling menghargai perbedaan.

Untuk menyikapi hal semua itu diperlukan paradigma berpikir baru. Paradigmayangdimaksudkan yaitu; paradigma berpikir multikultural, yakni paradigma berpikir yang bisa menghormati, tulus, dan toleran terhadap keanekaragamantersebut. ${ }^{3}$ Dalam penataan paradigma yang dimaksudkan di atas tidak bisa dilakukan dengan trial and error, tetapi harus terprogram, sistematis, dan berkesinambungan. Langkah yang paling strategis adalah melalui pendidikan, baik formal, non formal maupun informal dalam masyarakat. ${ }^{4}$

Pentingnya pendidikan multikultural dalam batas tertentu mendapat respon yang positif dari pihak eksekutif dan legislatif. Hal ini terbukti dengan diundangkannya UndangUndang Republik Indonesia No. 20 Tahun 2003 tentang Sistem Pendidikan Nasional, yang mengakomodasi nilai-nilai hak asasi manusia dan semangat keberagaman. Bahkan nilai-nilai tersebut dijadikan sebagai salah satu prinsip penyelenggaraan Pendidikan Nasional, sebagaimana yang termaktub pada Bab III pasal 4, ayat 1 dinyatakan bahwa:

"Pendidikan diselenggarakan secara demokratis dan keadilan serta tidak deskriminatif dengan menjunjung tinggi hak asasi manusia, nilai keagamaan, nilai kultural, dan kemajemukan." 5

MenurutM. Amin Abdullah, pendidikan agama Islam yang diajarkan selama ini masih bersifat statis (kaku) dan bersifat monokultur baik kurikulum, materi dan metode pembelajarannya, dengan mengabaikan keunikan dan pluralitas, memasung pertumbuhan pribadi yang kritis dan kreatif dimana materi yang diajarkan selama ini lebih disibukkan oleh urusan kalangan sendiri (individual affairs) dalam bentuk al-ahwal alsyakhsiyyah(individual morality) dan kurang peduli pada isu-isu umum dalam bentuk al-ahwal al-ammah (public morality). ${ }^{6}$

Pola pendidikan agama Islam semacam inilah yang dalam perkembangannya cenderung didasarkan kepada semangat kelompok. Ada beberapa bentuk keberagamaan yang berdasarkan kepada semangat kelompok yaitu parokialisme, sektarianisme,

\footnotetext{
${ }^{3}$ M. Zainuddin, "Pluralisme dan Dialog Antarumat Beragama", dalam al-'Adalah, Vol 10 No 2 (Jember: STAIN Press, 2007), hlm. 20, from: http://www.shaleholic.com. Diakses 28-10-2013

${ }^{4}$ Zakiyudin Baidhawy, Pendidikan Agama Berwawasan Multikultural, (Jakarta: Erlangga, 2005), VII

5 Departemen Pendidikan Nasional Dirjen Dikdasmen, Undang-Undang Republik Indonesia No. 20 Tahun 2003 tentang Sistem Pendidikan Nasional, (Jakarta: Depdiknas, 2003), hlm. 5

${ }^{6}$ M. Amin Abdullah, Studi Agama Normativitas dan Historitas, (Yogyakarta: Pustaka Pelajar, 1996), hlm. 140-142
} 
ghettoisme, tribalisme, fasisme dan ekslusivisme.Pendidikan agama Islam berwawasan multikultural menawarkan satu alternatif yang meliputi; 1) melakukan semacam pergeseran titik perhatian dari agama ke religiositas, 2) memasukkan kemajemukan, 3) menekankan pada pembentukan sikap berbasis pada pemanfaatan keragaman yang ada di masyarakat. ${ }^{7}$

Baik dan buruknya kurikulum, materi dan metode pembelajaran yang dipergunakan, sangat dipengaruhi oleh individunya atau the man behind the gun, antara unsur penunjangnya yaitu guru. Kehadiran seorang guru pendidikan agama Islam yang berkualitas, profesional, memiliki integritas,menguasai pemahamankeislaman yang komprehensif, inklusif dan multikultural yang kuat dalam dunia pendidikan tidaklah dilahirkan dengan sendirinya atau dibentuk secara instan, akan tetapi melalui proses, salah satunya melalui kegiatan supervisi akademik yang dilakukan oleh seorang pengawas.

Menurut Suharsimi Arikunto, kegiatan supervisi sesuai dengan konsep pengertiannya, dapat dibedakan menjadi dua, yaitu: (1) Supervisi Akademik, dan (2) Supervisi Administrasi. Supervisi akademik merupakan upaya membantu guru-guru mengembangkan kemampuannya mencapai tujuan pembelajaran. Dengan demikian, berarti, esensi supervisi akademik itu sama sekali bukan menilai unjuk kerja guru dalam mengelola proses pembelajaran, melainkan membantu mengembangkan kemampuan profesionalismenya. ${ }^{8}$

Dalam melaksanakan supervisi akademik, tentunya terlebih dahulu pengawas menyusun Rencana Kepengawasan Akademik (RKA), dengan melakukan telaah yang mendalam terhadap kurikulum, materi, metode dan evaluasi pembelajaran. Dengan memperhatikan hal-hal tersebut maka RKA yang disusun akan dapat lebih spesifik memberikan bimbingan dan pendampingan kepada guru agar mampu untuk melakukan pengembangan kurikulum maupun materi (bahan ajar) PAI aspek fiqih yang berwawasan multikultural.

Dari latar belakang masalah di atas, perlu dilakukan penelitian lebih mendalam untuk mendesain supervisi akademik, khususnya yang berkaitan dengan materi pendidikan agama Islam aspek fiqih berwawasan multikultural, dengan demikian penelitian ini berjudul; "Wawasan Multikultural Dalam Supervisi Akademik Pendidikan Agama Islam Aspek Fiqih (Studi Kasus di SMP Negeri Kabupaten Sintang".

\section{Rumusan Masalah}

Berangkat dari latar belakang masalah dalam penelitian ini dapat dirumuskan menjadi dua, yaitu:

\footnotetext{
${ }^{7}$ M. Amin Abdullah, Studi Agama..., hlm. 140-142

${ }^{8}$ Suharsimi Arikunto, Dasar-Dasar Supervisi, (Jakarta : Rineka Cipta, 2004), cet. IV. hlm. 5
} 
a. Apakah materi pendidikan agama Islam aspek fiqih di SMP Negeri 1, SMP Negeri 2, dan SMP Negeri 4 Sintang telah memuat prinsip-prinsip multikultural?

b. Apakah Rencana Kepengawasan Akademik (RKA) pengawas dalam materi pendidikan agama Islam aspek fiqih pada SMP Negeri Kabupaten Sintang berwawasan multikultural?

\section{Metode Penelitian}

a. Jenis Penelitian

Penelitian ini digunakan untuk mendeskripsikan tentang segala sesuatu yang berkaitan dengan materi pendidikan agama Islam (PAI) aspek fiqih pada SMP, dan RKA pengawas.Dalam penelitian ini digunakan jenis penelitian kualitatif.

\section{b. Sumber Data}

Sumber data dalam penelitian ini terbagi dua yaitu sumber data primer dan sumber data sekunder.Sumber data primer meliputi Rencana Pelaksanaan Pembelajaran (RPP) guru dan Rencana Kepengawasan Akademik (RKA) pengawas.Sedangkan sumber data sekunder terdiri dari bahan ajar materi pendidikan agama Islam aspek fiqih pada SMP Negeri Kabupaten Sintang.

\section{c. Metode Pengumpulan Data}

Dalam proses pengumpulan data, penulis menggunakan metode wawancara, dan metode dokumentasi.

\section{d. Landasan Teori}

\section{Pengertian Pendidikan Multikultural}

Menurut para pakar, antara lain: Emile Durkheim (1858-1917) dan Marcel Maus (1872-1950) menjelaskan bahwa kultur adalah sekelompok masyarakat yang menganut simbol-simbol yang mengikat dalam sebuah masyarakat untuk diterapkan. A.R. Radcliffe Brown (1881-1955) dan Bronislaw Malinowski (1884-1942) menggambarkan kultur sebagai sebuah praktik sosial yang memberikan support terhadap struktur sosial untuk memenuhi kebutuhan-kebutuhan individunya. ${ }^{9}$

Christine I Bennet dalam H.A.R. Tilaar, mengatakan pendidikan multikultural adalah sebuah pendekatan pada pengajaran dan pembelajaran yang didasarkan atas nilai dan kepercayaan demokratis dan melihat keragaman sosial dan interpendensi dunia sebagai bagian pluralitas budaya. ${ }^{10}$ Lee Manning memahami pendidikan multikultural pada proses pengajaran untuk menerima keragaman budaya, ras gender, dan kelas sosial ekonomi yang berbeda. ${ }^{11}$ Azra mendefinisikan, pendidikan

\footnotetext{
${ }^{9}$ Ngainun Naim dan Achmad Syauqi, Pendidikan Multikultural; Konsep dan Aplikasi, (Yogyakarta : AR-Ruzz Media, 2011), cet. III, hlm. 121-122

${ }^{10}$ Christine I Bennet, Comprehensive Multicultural Education: Theory and Practice, (USA: Simon \& Schuster Company, 1995), hlm. 13

${ }_{11}$ M.Lee Manning and Leroy G. Barutt, Multicultural Education of Children and Adolescent, (USA: A Pearson Education Company, 2000), hlm. 340
} 
multikultural sebagai pendidikan untuk atau tentang keragaman kebudayaan dalam merespon perubahan demografi dan kultur lingkungan masyarakat tertentu atau bahkan dunia secara keseluruhan. ${ }^{12}$

Dari penjelasan para ahli di atas dapatlah penulis tarik kesimpulan bahwa pendidikan multikultural ialah pendidikan yang memuat konsep dan aplikasi pembelajaran tentang menumbuhkan sikap untuk menghormati dan menghargai keragaman dalam kehidupan ini. Selain itu juga pendidikan multikultural dapat dimaknai sebagai sebuah proses pengembangan seluruh potensi manusia serta menghargai pluralitas dan heterogenisitasnya sebagai konsekuensi keragaman budaya, suku, etnis, agama dan aliran agama.

\section{Pengertian Supervisi Akademik}

Secara terminologis, supervisi akademik sering diartikan sebagai usaha bantuan kepada guru. Terutama bantuan yang berwujud layanan profesional yang dilakukan oleh kepala sekolah, dan supervisor untuk meningkatkan proses hasil belajar. ${ }^{13}$ Suharsimi Arikunto, menjelaskan bahwa supervisi akademik menitikberatkan pengamatan pada masalah akademik, yaitu yang langsung berada dalam lingkup pembelajaran yang di lakukan oleh guru untuk membantu siswa ketika sedang dalam proses belajar. ${ }^{14}$

Glickman, mendefinisikan supervisi akademik ialah: "Academic supervision is a series of activities to help teachers develop the ability to manage the learning process for the achievement of learning objectives". ${ }^{15}$

Berdasarkan pengertian para ahli pendidikan di atas dapatlah penulis pahami dan simpulkan bahwa supervisi akademik ialah serangkaian bentuk layanan profesional dari supervisor (pengawas dan kepala sekolah) yang diberikan kepada guru-guru untuk meningkatkan kualitas proses belajar mengajar, melalui bimbingan secara kontinyu dalam merancang konsep, metode dan materi pembelajaran, sehingga akan berdampak pada kualitas hasil belajar siswa.

\section{a. Tujuan Supervisi Akademik}

Suharsimi Arikunto, berpendapat bahwa secara umum supervisi bertujuan untuk memberikan bantuan teknis dan bimbingan kepada guru (dan staf sekolah yang lain) agar personil tersebut mampu meningkatkan kualitas kinerjanya, terutama dalam melaksanakan tugas, yaitu proses pembelajaran. ${ }^{16}$

\footnotetext{
${ }^{12}$ Azyumardi Azra, Pendidikan Multikultural; Membangun Kembali Indonesia Bhineka Tunggal Ika, dalam Tsaqafah, Vol. Nomor 2 Tahun 2003, hlm. 3

${ }^{13}$ Ali Imran, Supervisi Pembelajaran Tingkat Satuan Pendidikan, (Jakarta: Bumi Aksara, 2011), cet. I, hlm. 8

${ }^{14}$ Suharsimi Arikunto, Dasar-Dasar Supervisi..., hlm. 5 ASCD, 1981)

${ }^{15}$ Glickman, Development Supervision; Alternative Practice for Helping Teacher Improve Instruction, (Virginia:

${ }^{16}$ Suharsimi Arikunto, Dasar-Dasar Supervisi..., hlm. 40
} 
Dalam rumusan yang lebih rinci, Joesoef Djajadisastra mengemuka kan tujuan supervisi akademik sebagai berikut:

1) Memperbaiki tujuan khusus mengajar guru dan belajar siswa.

2) Memperbaiki materi (bahan) dan kegiatan belajar mengajar.

3) Memperbaiki metode, yaitu cara mengorganisasi kegiatan belajar mengajar.

4) Memperbaiki penilaian atas media.

5) Memperbaiki penilaian proses belajar mengajar dan hasilnya.

6) Memperbaiki pembimbingan siswa atas kesulitan belajarnya.

7) Memperbaiki sikap guru atas tugasnya. ${ }^{17}$

Berdasarkan pendapat para ahli tentang tujuan supervisi akademik, maka dapatlah penulis dapat simpulkan bahwa supervisi akademik bertujuan untuk:

1) Untuk memberikan bimbingan berupa arahan kepada guru dalam memperbaiki proses kegiatan belajar mengajar (KBM).

2) Untuk memberikan bimbingan kepada guru dalam mengembangkan konsep dan materi pembelajaran.

3) Untuk memberikan bantuan dan bimbingan kepada guru dalam memperbaiki metode dan model pembelajaran.

4) Untuk memberikan penyadaran dan pemahaman kepada guru tentang urgensinya memperhatikan hasil pembelajaran.

5) Supervisi dilakukan oleh pengawas atau kepala sekolah yang profesional.

6) Untuk memberikan konstribusi bagi pencapaian tujuan pendidikan baik jangka pendek, menengah maupun jangka panjang.

\section{Pengertian Pendidikan Agama Islam}

Pengertian pendidikan agama Islam dalam Garis-Garis Besar Pengajaran dinyatakan bahwa:

"Pendidikan Agama Islam adalah usaha sadar untuk menyiapkan siswa dalam meyakini, bimbingan pengajaran atau latihan dengan memperhatikan tuntutan untuk menghormati agama lain dalam lingkungan antar umat beragama dalam masyarakat untuk mewujudkan persatuan nasional".18

Adapun pengertian pendidikan agama Islam menurut para ahli, diantaranya, adalah:

\footnotetext{
${ }^{17}$ Joesoef Djajadisastra, Pengantar Administrasi Pendidikan, (Jakarta: Depdikbud, 1976)

${ }^{18}$ Depdikbud, Garis-Garis Besar Pengajaran, (Jakarta: Depdikbud, 1995), hlm. 1
} 
1) Marimba, menyatakan bahwa: "Pendidikan agama adalah bimbingan jasmani rohani berdasarkan hukum-hukum agama Islam menuju terbentuknya kepribadian utama menuju ukuran Islam". ${ }^{19}$

2) Menurut M. Arifin, pendidikan agama Islam adalah "usaha-usaha secara sadar untuk menanamkan cita-cita keagamaan yang mempunyai nilai-nlai lebih tinggi daripada pendidikan lainnya karena hal tersebut menyangkut soal iman dan keyakinan". 20

3) Menurut Abdurrahman An Nahlawi, pendidikan agama Islam adalah merealisasikan penghambaan kepada Allah dalam kehidupan manusia baik secara individu maupun secara sosial. ${ }^{21}$

Dari definisi di atas dapatlah penulis pahami, bahwa yang dimaksud dengan pendidikan agama Islam adalah suatu usaha yang dilakukan secara sadar dan sistematis yang diberikan melalui bimbingan kepada siswa baik secara jasmani maupun rohani berdasarkan ajaran agama Islam, bertujuan untuk menyiapkan siswa agar mampu memahami, terampil melakukan dan konsisten dalam mengamalkan ajaran agama Islam dikehidupan sehari-hari. Sehingga dengan demikian seluruh aspek kehidupan siswa akan sesuai dengan tuntunan agama Islam.

\section{Tujuan Pendidikan Agama Islam}

Dalam Peraturan Pemerintah Nomor 55 Tahun 2007 dinyatakan bahwa fungsi dan tujuan pendidikan agama yaitu:

"Membentuk manusia Indonesia yang beriman dan bertakwa kepada Tuhan Yang Maha Esa, serta berakhlak mulia dan mampu menjaga kedamaian dan kerukunan hubungan inter dan antar umat beragama. Pendidikan agama bertujuan untukberkembangnya kemampuan peserta didik dalam memahami, menghayati, dan mengamalkan nilai-nilai agama yang menyerasikan penguasaannya dalam ilmu pengetahuan, teknologi, dan seni".22

Dari penjelasan di atas dapatlah penulis pahami dan simpulkan bahwa tujuan pendidikan agama Islam adalah untuk meningkatkan pengembangan kemampuan peserta didik dalam memahami, dan menghayati nilai-nilai ajaran agama Islam, serta memiliki kecakapan, keterampilan dalam mempraktekkan atau mengamalkannya, dalam kehidupan sehari-hari. Kesemuanya itu dengan menyerasikan penguasaan ilmu pengetahuan dan teknologi (IPTEK) serta cakap dalam pengusaan seni budaya. Sehingga berfungsi dalam pembentukan karakter manusia (peserta didik) yang

\footnotetext{
${ }^{19}$ Ahmad A. Marimba, Pengantar Filsafat, (Bandung: PT. Al-Ma'arif, 1962), hlm. 27

${ }^{20}$ Muhammad Arifin, Hubungan Timbal Balik Pendidikan, (Jakarta: Bulan Bintang, 1985), hlm. 214

${ }^{21}$ Abdurrahman An Nahlawi, Pendidikan Islam di Rumah, Sekolah dan Masyarakat, (Jakarta: Gema Insani Pers, 2000), hlm. 117

${ }^{22}$ Peraturan Pemerintah Nomor 55 Tahun 2007 Tentang Pendidikan Agama dan Pendidikan Keagamaan, Bab II Pasal 2 ayat 1 dan 2
} 
bertaqwa kepada Tuhan Yang Maha Esa, berakhlak mulia dan mampu menciptakan serta menjaga kedamaian, kerukunan dalam ranah persatuan dan kesatuan inter dan antar umat beragama yang memiliki corak plural-multikultural.

\section{Materi Pendidikan Agama Islam Aspek Fiqih}

Berdasarkan Peraturan Pemerintah Nomor 32 Tahun 2013 Tentang Perubahan atas Peraturan Pemerintah Nomor 19 Tahun 2005 Tentang Standar Nasional Pendidikan Tingkat Kompetensi dan ruang lingkup materi pendidikan agama Islam pada SMP aspek fiqih yang diatur dalam Pasal 77I ayat (1), Pasal 77C ayat (1), dan Pasal 77K ayat (2), ayat (4) dan ayat (5) adalah sebagai berikut:

1) Materi PAI SMP Aspek Fiqih Kelas VII

a) Taharah.

b) Shalat wajib berjamaah dan munfarid.

c) Shalat Jum'at.

d) Shalat jamak dan qashar.

2) Materi PAI SMP Aspek Fiqih Kelas VIII

1) Shalat sunnah.

2) Macam-macam sujud.

3) Puasa wajib dan sunnah.

4) Zakat fitrah dan mal.

5) Binatang haram dan halal.

3) Materi PAI SMP Aspek Fiqih Kelas IX

1) Tata cara penyembelihan binatang kurban dan akikah.

2) Ibadah haji dan umrah.

3) Salat sunnah berjamaah dan munfarid.

\section{Pendidikan Agama Islam Berwawasan Multikultural}

Menurut Nurdin sebagaimana dikutip oleh Budiman Tahir, yang menjadi alasan dasar adanya rumusan konsep pendidikan agama Islam yang berwawasan multikultural diantaranya adalah; Pertama, bahwa Islam mengajarkan menghormati dan mengakui keberadaan orang lain. Kedua, konsep persaudaraan Islam tidak hanya terbatas pada sekte-sekte atau golongan saja.Ketiga, dalam pandangan Islam bahwa nilai tertinggi seseorang hamba adalah terletak pada integritas taqwa dan kedekatannya dengan Tuhan. ${ }^{23}$

Menurut M. Amin Abdullah, PAI yang berwawasanmultikultural bisa diinternalisasikan melalui pengembangan konsep (content) materi dan aplikasi pendidikan agama Islam dengan meliputi; Pertama, melakukan semacam pergeseran

${ }^{23}$ Budiman Tahir, Pendidikan Agama Islam Dalam Prespektif Multikulturalisme, (Jakarta : Balitbang Agama, 2009), hlm. 75 
titik perhatian dari agama ke religoisitas.Kedua,memasukkan kemajemukan.Ketiga, menekankan pada pembentukan sikap berbasis pada pemanfaatan keragaman yang ada di masyarakat, khususnya yang ada pada siswa seperti keragaman etnis, budaya, bahasa, agama, status sosial, gender, kemampuan, umur, dan lain sebagainya.

Adapun dalam aplikasi atau pengajaran materi pendidikan agama Islam tidak bersifat statis(kaku) dan monokultur yang meliputi; Pertama,bukan hanya ilmu-ilmu keislaman klasik akan tetapi pendekatan keilmuan sosial keagamaan yang berkembang saat ini juga penting diajarkan. Kedua,tidak bersifat doktrinal, melainkan perlu dikedepankan uraian dimensi historis dari doktrin-doktrin keagamaan tersebut.

Ketiga, tidak hanya bertumpu kepada tekstual tapi perlu juga secara konstekstual dengan memerlukan ilmu-ilmu bantu yang diambil dari disiplin psikologi, sejarah, filsafat, sosiologi, ekonomi, politik dan ilmu-ilmu, untuk menjelaskan hakikat, visi dan misi agama Islam yang fundamental. Keempat, dalam materi pembelajaran PAI tidak hanya harus bermuatan ilmu kalam akan tetapi ilmu tasawuf juga harus disampaikan. Kelima, pembentukan keshalihan sosial bukan hanya keshalihan individual semata. ${ }^{24}$

Dari penjelasan para ahli di atas dapat penulis pahami dan simpulkan bahwa dalam pendidikan agama Islam berwawasan multikultural adalah bagaimana nilainilai atau pun prinsip-prinsip pendidikan multikultural dapat diinternalisasikan ke dalam konsep (content) materi pendidikan agama Islam, yang endingprosesdiaplikasikan pada proses pembelajaran. Dengan kata lain, PAI yang berwawasan multikultural adalah proses pembelajaran PAI di sekolah yang memperhatikan segala macam keragaman dalam diri agama Islam itu sendiri. Jelasnya jika dalam konsep pendidikan agama Islam memuat prinsip-prinsip pendidikan multikultural yang diaplikasikan melalui proses pembelajaran di sekolah maka akan dapat melahirkan peradaban, yang juga melahirkan sikap toleransi, tenggang rasa, demokrasi, tolong menolong, keadilan, keharmonisan, dan nilai-nilai kemanusian lainnya.

\section{HASIL PENELITIAN DAN PEMBAHASAN}

\section{Materi Pendidikan Agama Islam Aspek Fiqih}

Dari hasil analisis penelitian dokumen isi materi PAI SMP aspek fqih yang terdapat pada kelas tujuh, delapan, dan sembilan untuk semester ganjil dan genapdan wawancara kepada guru PAI, menurut penulis untuk materi tersebut masih harus dikembangkan karena acapkali banyak ditemukan penjelasan materi yang mengandung ambiguitas disebabkan sedikit sekali bahkan tidak ada sama sekali mencantumkan kutipan landasan normatif baik ayat al-Qur'an, dan hadis (dalil naqli) maupun pendapat ulama fiqih (dalil aqali).Oleh karena itu materi yang disajikan terkesan

\footnotetext{
${ }^{24}$ M. Amin Abdullah, Pendidikan Agama Era Multikultural-Multireligius, (Jakarta: PSAP, 2005), hal. 78-71.
} 
ambiguitas dan membiaskan kepada salah satu paham keagamaan atau mazhab fiqih tertentu.

Adapun untuk materi pendidkan agama Islam aspek fiqih pada sekolah menengah pertama saat ini masih belum berwawasan multikultural. Contoh konkritnya adalah: Pertama, pada penjelasan materi taharah, masih adanya penulisan lafaz niat wudu, tayamum dan mandi wajib. Kedua, pada penjelasan materi puasa yaitu tentang hal-hal yang membatalkan puasa salah satu diantaranya adalah dengan melihat (ru'yat)bulan.Dalam penjelasan ini hanya dijelaskan satu metode saja dalam penentuan atau penetapan awal bulan hijriah.Padahal menurut penulis penentuanatau penetapan awal bulan tersebut tidak hanya menggunakan metode ru'yat namun ada juga metode hisab.Ketiga, pada setiap penjelasan penetapan hukum ibadah dan ketentuannya tidak ada penjelasan yang lebih spesifik pada pandangan atau pendapat ulama mazhab fiqih.

Sebaliknya, dikatakan belum berwawasan multikultural apabila isi (content)materi ajarbelum bermuatan nilai-nilai multikultural, yaitu: adil, setara, dan demokratis.Adil dalam artian isi materi hendaknya dikembangkan dengan memuat pendapat para ulama fiqih dari semua mazhab. Sedangkan setara dimaksudkan adalah bagaimana muatan materi tersebut memberikan porsi yang sama dalam mengakomodir pendapat ulama. Adapun demokratis ialah muatan isi materi tidak bias kepada salah satu pandangan ulama mazhab tertentu.

\section{Rencana Kepengawasan Akademik}

Berdasarkan hasil pengamatan dokumen dan wawancara, menurut penulis sampai saat ini Pokjawas PAI Kankemenag belum merancang Rencana Kepengawasan Akademik PAI yang lebih spesifik dari masing-masing aspek baik itu aspek akidah, alQur'an-hadis, akhlak, dan fiqih serta tarikh (sejarah Islam) yang merupakan materi dalam pendidikan agama Islam SMP. Apalagi untuk materi PAI aspek fiqih yang berwawasan multikultural.Rancangan kepengawasan akademik yang telah ada masih bersifat global (umum) bahkan lebih difokuskan kepada pengelolaan kegiatan belajar mengajar (KBM) dan administrasi (perangkat pembelajaran) guru.

Namun dengan demikian pengawas sangat memberikan motivasi kepada guru PAI SMP untuk melakukan analisis kurikulum khususnya analisis materi pelajaran PAI aspek fiqih yang kemudian ditindaklanjuti dengan pengembangan.Pengembangan PAI aspek fiqih yang berwawasan multikultural merupakan sebuah keniscayaan karena fiqih merupakan satu disiplin ilmu untuk memahami ketentuan ibadah.Apalagi di tengah masyarakat yang plural, heterogen dari semua sisi atau aspek.

Idealnya menurut penulis sudah merupakan sebuah keniscayaan bagi pengawas untuk membuat Rencana Kepengawasan Akademik (RKA) yang lebih spesifik pada setiap aspek dalam pendidikan agama Islam, terlebih khusus pada aspek fiqih yang memuat nilai-nilai multikultural. Dengan demikian pengawas ketika melaksanakan 
supervisi akademik tidak stagnan atau hanya terfokus pada proses pembelajaran dan administrasi, namun ia mampu memberikan bimbingan kepada guru dalam mengembangkan materi melalui Rencana Pelaksanaan Pembelajaran (RPP) aspek fiqih berwawasan multikultural pada setiap jenjang kelas SMP.

\section{PENUTUP}

Materi PAI aspek fiqih SMP yang terdapat pada kelas tujuh, delapan, dan sembilan semester ganjil dan genap masih belum berwawasan multikultural karena setelah dilakukan analisis mendalam acapkali banyak ditemukan penjelasan materi yang mengandung ambiguitas disebabkan sedikit sekali bahkan tidak ada sama sekali mencantumkan kutipan landasan normatif baik ayat al-Qur'an, dan hadis (dalil naqli) maupun dalil naqli atau pendapat ulama fiqihdari berbagai mazhab. Oleh karena itu materi yang disajikan terkesan membiaskan kepada salah satu paham keagamaan atau mazhab fiqih tertentu. Pengembangan materi pendidikan agama Islam aspek fiqih merupakan sebuah keniscayaan dengan memasukan nilai-nilai atau pun prinsip-prinsip multikultural bentuk konkritnya adalah dengan memuat pandangan semua mazhab fiqih.

Untuk terlaksananya kegiatan supervisi akademik diharuskan setiap pengawas mampu menyusun RKA PAI yang lebih spesifik pada setiap aspek.Jika melihat dokumen rencana RKA tahun pelajaran 2013/2014 semester ganjil/genap yang disusun oleh Pokjawas PAI, maka penulis belum menemukan desain supervisi akademik yang lebih spesifik pada mata pelajaran pendidikan agama Islam asfek fiqih.Rancangan kepengawasan akademik yang ada masih bersifat global (umum) bahkan lebih difokuskan kepada pengelolaan kegiatan belajar mengajar (KBM) di kelas dan administrasi (perangkat pembelajaran) guru. 


\section{DAFTAR PUSTAKA}

A. Ahmad Marimba, Pengantar Filsafat. Bandung: PT. Al-Ma'arif, 1962.

Abdullah M. Amin, Studi Agama Normativitas dan Historitas.Yogyakarta: Pustaka Pelajar, 1996.

--------,Pendidikan Agama Era Multikultural-Multireligius. Jakarta:PSAP, 2005.

Abdurrahman An Nahlawi, Pendidikan Islam di Rumah, Sekolah dan Masyarakat. Jakarta: Gema Insani Pers, 2000.

Ahmad Syahid, Peta Kerukunan Umat Beragama Provinsi Bengkulu.Jakarta: Depag RI, 2003.

Ali Imran, Supervisi Pembelajaran Tingkat Satuan Pendidikan. Jakarta: Bumi Aksara, 2011.

Azyumardi Azra, Pendidikan Multikultural; Membangun Kembali Indonesia Bhineka Tunggal Ika, dalam Tsaqafah, Vol. Nomor 2 Tahun 2003.

Barutt G Leroy and M.Lee Manning, Multicultural Education of Children and Adolescent. USA: A Pearson Education Company, 2000.

Bennet I Christine I Bennet, Comprehensive Multicultural Education: Theory and Practice.USA: Simon \& Schuster Company, 1995.

Departemen Pendidikan Nasional Dirjen Dikdasmen, Undang-Undang Republik Indonesia No. 20 Tahun 2003 tentang Sistem Pendidikan Nasional. Jakarta: Depdiknas, 2003.

Depdikbud, Garis-Garis Besar Pengajaran. Jakarta: Depdikbud, 1995.

Djajadisastra Joesoef, Pengantar Administrasi Pendidikan. Jakarta: Depdikbud, 1976.

Glickman, Development Supervision; Alternative Practice for Helping Teacher Improve Instruction. Virginia: ASCD, 1981.

Muhammad Arifin, Hubungan Timbal Balik Pendidikan, Jakarta: Bulan Bintang, 1985.

Ngainun Naim dan Achmad Syauqi, Pendidikan Multikultural; Konsep dan Aplikasi.Yogyakarta: AR-Ruzz Media, 2011.

Peraturan Pemerintah Nomor 55 Tahun 2007 Tentang Pendidikan Agama dan Pendidikan Keagamaan.

Suharsimi Arikunto, Dasar-Dasar Supervisi. Jakarta: Rineka Cipta, 2004. 
Syamsul Arifin, Silang Sengkarut Agama di Ranah Sosial Tentang Konflik, Kekerasan Agama dan Nalar Multikulturalisme. Malang: UMM Press, 2009.

Tahir Budiman, Pendidikan Agama Islam Dalam Prespektif Multikulturalisme. Jakarta: Balitbang Agama, 2009.

Tilaar.H.A.R, Multikulturalisme; Tantangan-tantangan Global Masa Depan Dalam Transformasi Pendidikan Nasional. Jakarta: Grasindo,2004.

Zainuddin. M, "Pluralisme dan Dialog Antarumat Beragama", dalam al-'Adalah, Vol 10 No 2 Jember: STAIN Press, 2007.

Zakiyudin Baidhawy, Pendidikan Agama Berwawasan Multikultural. Jakarta: Erlangga, 2005. 